\title{
Geometric morphometrics of leaves of Cynanchum acutum L. (Apocynaceae) from Egypt
}

\author{
Faten Y. Ellmouni
}

Botany Department, Faculty of Science, Fayoum University,63514, Fayoum, Egypt

Corresponding author: E-mail address: fyl00@fayoum.edu.eg

\begin{abstract}
This study aimed to revise Cynanchum acutum in Egypt and their relative subspecies that belonging to Section Cynanchum (Old World) and comparing it with an American group of genera Cynanchum laeve subgen. (Sect.) Mellichampia (New World) by using classical taxonomy and Modern geometric morphometric methods (GMMs). The description of 85 specimens depending on 36 quantitative traits was measured for all leaves by ImageJ Tool software. Data of leaf description was further processed using $R$ program. The fan neighbor-joining topology revealed to the relationship between studied taxa and population, however, a PCA biplot showed a total variation $37.7 \%$ at first axis and $\mathbf{8 . 9} \%$ at the second axis. Significant variation in taxa and populations estimated using ANOVA and MANOVA. Canonical variate analysis showed a significant difference between taxa $\left(\mathrm{P}=0.001^{* * *}\right)$, with a total variation of $67 \%$ between three taxa. The total variation checked between two taxa by using discriminant analysis, C. acutum subsp. acutum and C. acutum subsp. sibiricum calculated $77 \%$ variation, while as the total variation between then between $C$. acutum subsp. acutum and $C$. laeve showed $86 \%$ of the variation and significant value $(P=0.002 * *)$. The study elucidated the situation of Cynanchum acutum in Egypt and confirmed the presence of two subspecies viz.: subsp. acutum and subsp. sibiricum.
\end{abstract}

Keywords: Cynanchum acutum, Modern geometric morphometric methods, leaf architecture, Egypt.

\section{Introduction:}

The Cynanchum L. genus formerly situated as part of Asclepiadaceae however according to the several phylogenetic studies, Asclepiadaceae treated as a subfamily of Apocynaceae to be Asclepiadoideae (Goyder et al. 2007; Rapini et al. 2007; Endress 2016; Nam \& Chung 2018). Cynanchum has been worldwide distributed with more than 400 species over the Old and the New World and about 110 species extent in Africa, Madagascar considers the main center of diversity in Africa with nearly 90 species, in contrast, the minor centers are southern Africa and eastern Africa with 10 -15 species each (Liede 1997; Liede 1999; Liede \& Kunze 2002; Alvarez Cruz \& Schmelzer 2012; Khanum et al. 2016).

The last treatment of Cynanchum in Egypt was done by Boulos (2000) who recognized only one species of Cynanchum at Egypt "Cynanchum acutum", with one subspecies "subsp. acutum", in agreement with
Täckholm (1974) and Greuter et al. MedChecklist 1 1984. On the other hand, Boulos, in Flora Checklist (1995) revealed the presence of two subspecies in Egypt "subsp. sibiricum" and "subsp. acutum", the main difference between two subspecies is the leaf shapes, lengths, and base lobe. Gilbert et al. (1995) were stated to $C$. acutum subsp. acutum is most common in the Mediterranean region where there is an overlapping area with $C$. acutum subsp. sibiricum.

The leaf morphology is the main discriminative power in plant taxonomy and systematics (Bell and Bryan 2008; Cope et al. 2012). Leaf morphometric is commonly used in several fields, such as morphology, systematic taxonomy, developmental biology, plant breeding, and agronomy (Vieira et al. 2014). Modern geometric morphometric methods (GMMs) contribute to increasing scientific description accuracy for the 


\section{Geometric morphometrics of leaves of Cynanchum acutum $\mathrm{L}$.}

important traits of the phenotypic measurement at biodiversity and proper for differentiating complex taxa. In contrast to classical taxonomy requires handling and admission to specimens (Viscosi and Cardini 2011; Klein and Svoboda 2017; Liu et al. 2018).

Therefore, it is appropriate to apply the morphology of leaf to examine the presence of subspecies "Cynanchum acutum" at Egypt by using modern geometric morphometric methods with assessment of taxonomic treatment and leaf architecture. In additional to, analyzing the results by focusing on Cynanchum acutum populations, to decide suitable distinctive traits to distinguish between Cynanchum acutum subspecies by comparison both with Cynanchum laeve as outgroup.

\section{Material and Methods}

\subsection{Study site and plant material}

Field survey of the Cynanchum acutum location in Fayoum depression (FD) took place during summer 2017 (Fig. 1, Suppl.1). Fayoum depression (FD) is situated at 90 Kilometers to the southwest of Cairo, the coordinates: $28^{\circ} 55^{\prime}-29^{\circ} 35^{\prime} \mathrm{N}, 30^{\circ} 23^{\prime}-31^{\circ}$ 05' E (Effat, \& El-Zeiny, 2017). Detailed investigation of samples and the population gathered from studying Herbarium sheet kept at Cairo University herbarium (CAI), collected samples from FD and Images from Florida Herbarium site for Cynanchum laeve. Description of 85 specimens (Suppl.2) with a total 105 observation from one to three leaves to each branch were measured. The quantitative measurement totally 36 summarized in table (1), leaf descriptors were carefully chosen concerning conclusions of studies by other authors (e.g. Zahidi et al. 2013; Baláš et al. 2016; Aykut et al. 2017; Lo Bianco and Mirabella 2018). Digital images were used to measure the different measured traits using ImageJ Tool program (Rasband 1997-2018).

\subsection{Data analysis}

Data from leaf descriptors were further processed in program R (R Development Core Team, 2016).
2.2.1. Testing variation in taxa and populations, using multivariate methods (Cluster analyses and ordination analyses):

For agglomerative clustering the standardization must be done to make variable comparable. Removing the lines with missing data and standardize the data without missing values. Firstly, to standardize the data, it should be converted to a numeric matrix as an input to complete the scaling on the column. Secondly, the Gower-dissimilarity is used, the data scaled and computed a Manhattan distance (Viscosi and Cardini 2011; Kassambara 2017). Selecting neighbor-joining (NJ) tree by calculating the cophenetic correlation which is better than that at Unweighted Pair Group Method with Arithmetic Mean (UPGMA).

The "factoextra" and "ggplot2" packages in $\mathrm{R}$ were used for visualizing the distance matrices that used at the Principal Component Analysis. PCA was used to know the total variation of leaf traits and identified the most important trends in leaf shape (Vieira et al. 2014). PCA decreases the dimensionality of multivariate data, to two or three that can be visualized graphically with minimal loss of information. fviz_pca provides ggplot2- based stylish visualization of PCA (Kassambara 2017).

2.2.2. Testing variation in taxa and populations, using a modified Procrustes ANOVA

Differences in leaf descriptors can chart in several planes. A hierarchical analysis of variance (ANOVA) generated to measure and test the variation in taxa and geographical populations using (aov) function, and the measuring the size ( $\mathrm{t}$-value) was calculated by summary (lm) function, as well as testing the significant of variables by manova function of package "dplyr" for multivariate analysis of variance (MANOVA).

\subsubsection{Testing taxa differences using permutation tests and discriminant analyses}

By utilizing a series of $\mathrm{R}$ functions of morphometric analysis (MorphoTools) were performed descriptive statistics for populations and taxon, Box-and-whisker plots representing all leaf descriptors to display the variation range between three investigated 


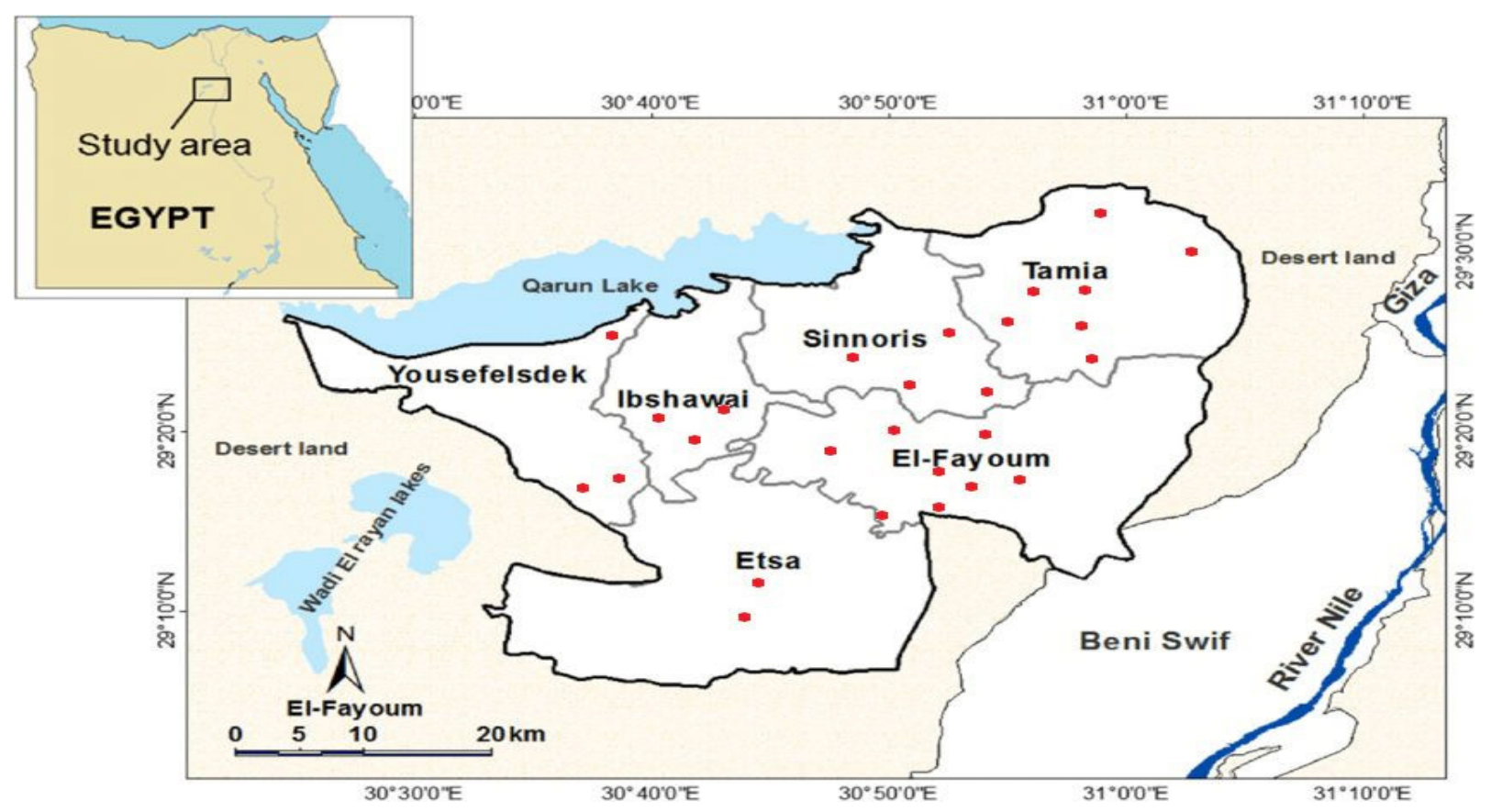

Fig.1. Distribution map of the collected Cynanchum acutum subsp. acutum in Fayoum depression during summer 2017.

taxa, Canonical Variate Analysis (CVA) intended for discriminant test to three taxa and Discriminant Analysis (DA) for comparison of the two subspecies (Koutecký 2015).

\section{Results}

\subsection{Systematic treatment}

Cynanchum L. Sp. PI. 212 (1753).

Type: Cynanchum acutum L. designated by E. Meyer (1837).

Perennial twining, climbing or erect, subshrubs or herbs. Multicellular Hair or glabrous. Yellow to white milky latex. Fibrous, fleshy or woody roots. Greenish stem. Leaves opposite, petiolate, usually cordate, elliptical, ovate or obovate with entire margin and acute apex. Leaves sometimes have small leafy stipule. Inflorescences extra-axillary, raceme-like, corymbose or umbel-like. Flowers 3-15 mm diameter; aestivation imbricate or contorted, dextrorse; nectariferous. Calyx free \pm to the base with erect sepals, frequently have basal glands. Corolla deeply divided, contorted in the bud, rotate, sub-rotate to tubular, white, green, yellow or rarely reddish. The crown (corona) as high as, higher than or inserted on base the gynostegium; campanulate or tubular; white, rarely red; fleshy or membranous, divided into
10 free fringes; the 5 outer segments tridentate and longer than 5 inside and opposite to the outer ones. Filaments united in a tube, membranous Anther with apical appendages, ovate pollinia with 2 per pollinarium, divergent, pendulous. Pentagonal stigma with 2 apical tubercles. Follicle solitary lanceolate or fusiform smooth or with bulges, glabrous or hairy, winged or wingless, thin-walled. Seeds ovate or boat-shaped, smooth, brown, papillate or with trichomes, sculptured, winged or wingless, with coma. Chromosome number usually 2n = 22 (Davis, 1978; Rechinger, 1970; Forster, 1991; Li et al., 1995; Liede, 1999).

Speciose Cynanchum genus worldwide distribution; over than 400 species, here, the study focusses in literature and synonyms for Egyptian species Cynanchum acutum (Old World) belong to Sect. Cynanchum and linkage it with more resembling Cynanchum laeve (New World) subgen. Mellichampia by cordate (heart-shaped) leaves as out group taxa (Liede \& Täuber 2002; Liede \& Meve, 2003; Khanum et al. 2016).

Based on revision of the Herbarium sheet kept at (CAI) and study the description of C. acutum subspecies in different flora like Flora of Egypt, Flora of Iranica, Flora of 


\section{Geometric morphometrics of leaves of Cynanchum acutum $\mathrm{L}$.}

Table 1. List of investigated leaf measurements used for morphometric analysis with illustration

\begin{tabular}{|c|c|}
\hline Leaf Trait & Abbreviation \\
\hline Lamina length & LL \\
\hline Maximal width of lamina & MWL \\
\hline Middle width of lamina & MW \\
\hline $\begin{array}{c}\text { The distance between the widest point and } \\
\text { the leaf tip }\end{array}$ & DTW \\
\hline $\begin{array}{c}\text { The distance between the widest point and } \\
\text { the leaf base }\end{array}$ & DBW \\
\hline Laminar ratio & $\mathrm{LR}=\mathrm{MWL} / \mathrm{LL}$ \\
\hline Area of leaf (laminar size) & LA \\
\hline Petiole length & PL \\
\hline Total leaf length & $\mathrm{TLL}=\mathrm{LL}+\mathrm{PL}$ \\
\hline Petiole length x 100/total leaf length & $\begin{array}{c}\mathrm{P} \%=\mathrm{PL} \times 100 \\
\text { /TLL }\end{array}$ \\
\hline $\begin{array}{c}\text { Middle width of lamina x 100/total leaf } \\
\text { length }\end{array}$ & $\begin{array}{c}\text { MW\%= MW x } 100 \\
\text { /TLL }\end{array}$ \\
\hline $\begin{array}{c}\text { Maximal width of lamina x 100/total leaf } \\
\text { length }\end{array}$ & $\begin{array}{c}\text { MWL\%= MWL } \times 100 \\
\text { /TLL }\end{array}$ \\
\hline $\begin{array}{l}\text { leaf surface as the product of the length } \\
\text { and maximum width }\end{array}$ & SURF= LL x MWL \\
\hline Petiole sinus depth & $\mathrm{H}-\mathrm{SP}$ \\
\hline Length of main vein & V1 \\
\hline Length of vein 2 (left) & $\mathrm{V} 2$ \\
\hline Length of vein 3 & V3 \\
\hline Length of vein 4 & V4 \\
\hline Length of vein 5 & V5 \\
\hline Length of vein 6 & V6 \\
\hline Length of vein 7 & V7 \\
\hline Length of vein 8 & V8 \\
\hline Length of vein 9 & V9 \\
\hline Length of vein 10 & V10 \\
\hline Petiole sinus angle (concave up) & $\mathrm{T} 1$ \\
\hline Inner angle V2+4 (left) & $\mathrm{T} 2$ \\
\hline Inner angle V3+5 & T3 \\
\hline Inner angle V6 & $\mathrm{T} 4$ \\
\hline Inner angle V7 & $\mathrm{T} 5$ \\
\hline Inner angle V8 & T6 \\
\hline Inner angle V9 & $\mathrm{T} 7$ \\
\hline Inner angle V10 & $\mathrm{T} 8$ \\
\hline Petiole vein angle (3rd order, left) & $\mathrm{Z1}$ \\
\hline Petiole vein angle (3rd order, right) & $\mathrm{Z} 2$ \\
\hline Apex angle & T9 \\
\hline
\end{tabular}
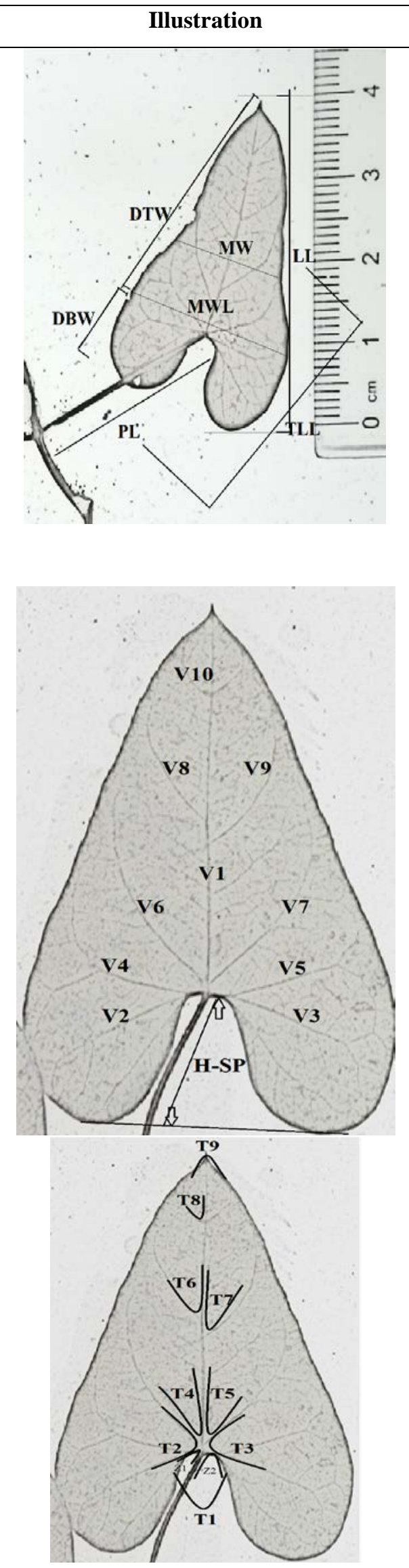
Turkey and Flora of China have been showed that the main difference is the shape and base lobe of leaf between two subspecies with variable data for leaves as shown in table (2). The present study confirms of existence $C$. acutum subsp. sibiricum in Egypt at Nile Delta, Siwa Oasis and Baharia Oasis, is being in line with the first record of C. acutum subsp. sibiricum in Egypt Boulos, Flora Checklist (1995), Fig. (2).

The elementary venation pattern of $C$. acutum and $C$. laeve appear to the correspondence at the leaf architecture; which are pinnate, the secondary vein doesn't reach to margin (Camptodromous), these 2nd veins connected in a series of conspicuous curvatures (brochidodromous), with Irregular vein spacing and the vein angle abruptly increasing toward the base. The Intersecondary veins present. Random reticulate is characterize to third vein category called tertiaries anastomose with acute vein and regular polygonal reticulate fourth vein. The arola was moderately or poorly, all these characters appear naked eye (Fig. 3).

\section{Sect. Cynanchum (Old World)}

Cynanchum acutum L., Sp. PI. 212 (1753).

Syn: Cynanchum monspeliacum L, Sp. Pl. ed.1: 212 (1753).

Stems terete, up to $3 \mathrm{~m}$, herbaceous, slender, vine, branched, lower parts glabrous, sometimes hairy above. Petiolate leaves, glabrous, cordate, ovate, very variable in shape and size, 2-10 (-17) x 1.5-8 (-16) cm apex subacute to acute, variable in base auriculate, deeply cordate to sagittate. Inflorescences Cymos, few- to many-flowered, peduncles 5$10 \mathrm{~cm}$, pubescent. Calyx (1.5-2) mm long, triangular lobes. Corolla white or pink, 6-9 mm diameters, lobes oblong and obtuse. Follicles 6-16 x $1 \mathrm{~cm}$, narrow, glabrous or papery when young, acuminate.

\section{Artificial Key to subsp. of Cynanchum acutum based on morphological characters}

1. The leaves one to double as long as broad, broadly ovate-cordate or narrow linear; basal lobes scarcely divergent, convex sides (broadly auriculate). Follicles $6-15 \mathrm{~cm}$ subsp. acutum 2. The leaves one to triple as long as broad, broadly cordate to hastate-cordate, or oblong-hastate; basal lobes distinctly divergent concave sides (auriculate). Follicles $12.5-16 \mathrm{~cm}$ subsp. Sibiricum

\section{Cynanchum acutum subsp. acutum.}

The leaves one to double as long as broad, up to 9 x $7 \mathrm{~cm}$; broadly ovate-cordate or narrow linear; basal lobes scarcely divergent, convex sides (broadly auriculate). Corona linguiform; appendages longer than lanceolate. Follicles $6-15 \mathrm{~cm}$.

\section{Representative specimens:}

Faculty of agriculture, farms, Alexandria; 28.8.1953; Loutfy Boulos; s.n. (CAI). Faculty of agriculture farm, Alexandria Univ., Alexandria; 28.8.1952; Nabil El Hadidy s.n. (CAI). Masraf El Gabaroti, El Aslah Mohatta, on the road Alexandria-Rosetta, Alexandria; 18.9.1970; Imam, Ibrahim, Mahdi;s.n. (CAI).Meshanded 25Km West of Siwa, Siwa Oasis; 26.10.1963; Loutfy Boulos s.n.(CAI).Siwa oasis/ Abu Sharour, Siwa Oasis; 1/4/1968; Gun Romeé \& N. El Hadidy s.n.(CAI).Siwa oasis; 27.12.1969;M. A. Zahran \& L. Boulos s.n. (CAI).Baharia Oasis,
Zabou;11.9.1971;M. Imam s.n.(CAI).Baharia Oasis, Al-Zabw;4.10.1978;Monier Abd El Ghani; s.n.(CAI).Baharia Oasi, Al-Harra, Ain Boulol, on walls \& hedges; 24.10.1979; Monier Abd El Ghani; s.n.(CAI). Baharia Oasis, Al-Zabw; 18.7.1978; Monier Abd El Ghani; s.n. (CAI). Giza near Cairo; 19.10.1910; E. Hartmann; s.n. (CAI). Orman Gardens, Giza; 6.10.1954; Soliman Sisi s.n. (CAI). Giza, 10.10.1967; M. El-Mahdi s.n. (CAI). At Parks and gardens, Orman Gardens, Giza; 27.8.1963; Mohammed El-Mahdi; s.n. (CAI). At Parks and gardens, Giza; 10.10.1967; Mohammed El-Mahdi s.n.(CAI). Beheira province, Rosetta; 16.7.1987; Alaa Amer; s.n. (CAI). Beheira; 29.9.1966; Nabil, Imam \& V. Tackholm s.n. (CAI). Wadi El Natraun, in Olive orchard, Beheira; 18.7.2009; A. Farhat s.n. (CAI). Boghaz, Rosetta, Beheira; 30.10.1971; Imam, Ibrahim, Mahdi s.n. (CAI). Dakahlia- Aga, Dakahlia; 


\section{Geometric morphometrics of leaves of Cynanchum acutum L.}

Table 2. Comparison between two subspecies of C. acutum based on information collected from different floras book, showed how much the variation of leaves between two subsp.

\begin{tabular}{|c|c|c|}
\hline & C. acutum subsp. acutum & C. acutum subsp. sibiricum \\
\hline Flora of Iranica (Rechinger 1970) & $\begin{array}{l}\text { The leaves up to } \pm 9 \times 7 \mathrm{~cm} \text {, narrow } \\
\text { linear, lobes of the basal of leaf } \\
\text { separate oblong as well } \\
\text { suborbiculate very divergent } \\
\text { provided sinus wide open. }\end{array}$ & $\begin{array}{l}\text { The leaves up to } \pm 10 \times 3 \mathrm{~cm} \text {, } \\
\text { broadly-cordata, usually a large one } \\
\text { to double times longer than sinus } \\
\text { and lobes of the basal diverging } \\
\text { from their blade barely separated. }\end{array}$ \\
\hline Flora of Turkey (Davis 1978) & $\begin{array}{l}\text { Leaves } 1-2(\mathrm{x}) \text { as long as broad, } \\
\text { broadly ovate-cordate with scarcely } \\
\text { divergent basal lobes. }\end{array}$ & $\begin{array}{l}\text { Leaves } 3 \text { or more } \mathrm{x} \text { as long as broad, } \\
\text { narrowly sagittate with distinctly } \\
\text { divergent basal lobes. }\end{array}$ \\
\hline Flora of China (Li et al. 1995) & $\begin{array}{l}\text { having ovate leaves with convex } \\
\text { rather than concave }\end{array}$ & $\begin{array}{l}\text { leaf blade hastate, hastate- cordate, } \\
\text { or oblong-hastate, base auriculate, } \\
\text { apex acute to long acuminate, basal } \\
\text { lobes recurved, parallel or divergent, } \\
\text { ciliate }\end{array}$ \\
\hline
\end{tabular}

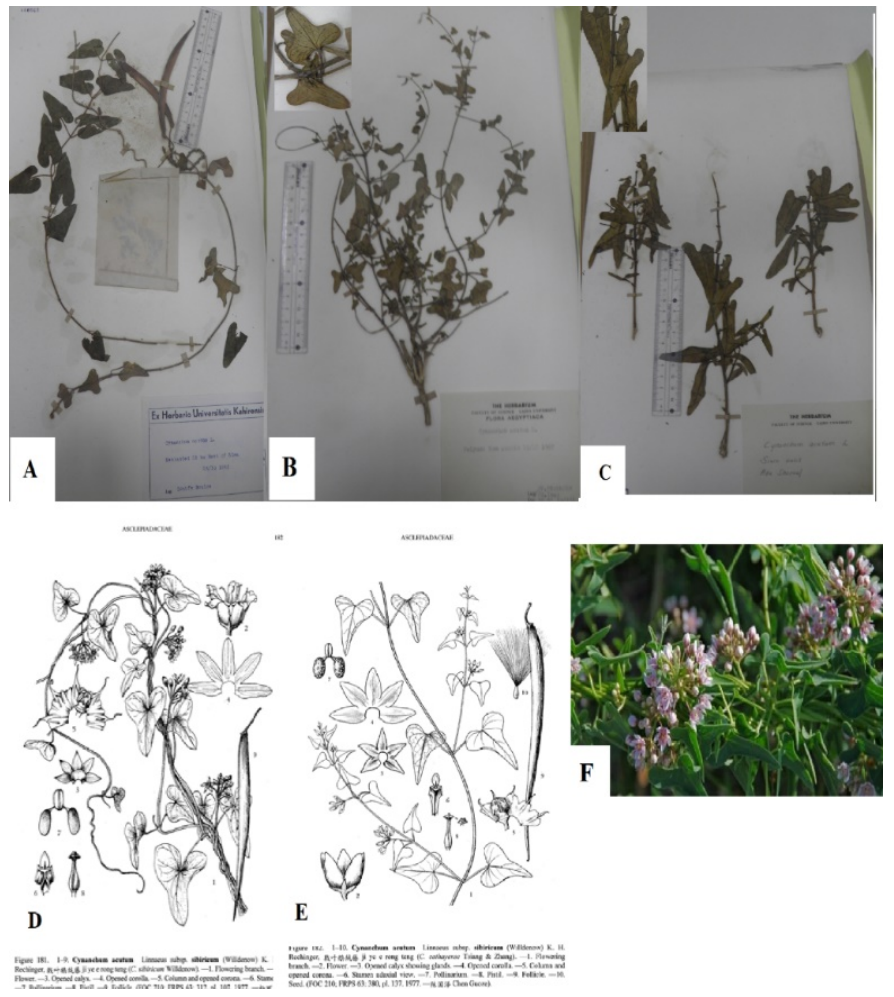

Fig. 2. The figures compare C. acutum Herbarium specimen sheet kept at (CAI) (A, B and C) by illustration of Flora of China (D and E), and F pic downloaded from” https://images.app.goo.gl/VLFQPkWf1Uwm3P18A”, to confirm the presence of C. acutum subsp. sibiricum by Image comparison method, and Written description.
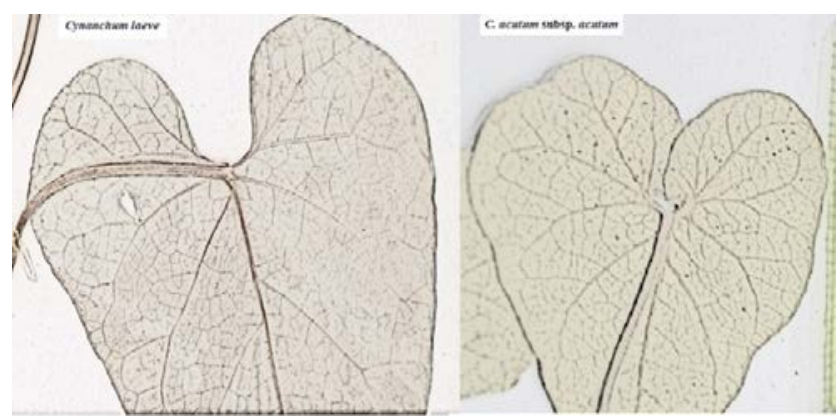

Fig. 3. the leaf architecture, show the venation pattern for C. acutum subsp. acutum and C. laeve seem to be similar. 
11.10.1929; E. Greiss s.n. (CAI). Between Ras el Bar and Demietta, 13.9.1929; M.T. Hefnawy s.n. (CAI). East of the Nile Delta/ ElManeyl, East; 17.6.1980; A. Bakry; s.n. (CAI). East of the Nile Delta, El-Mullok, 25.4.1980; A. Bakry; s.n. (CAI). Cairo: Ain Shams University; 1977; A. Gazzar; s.n. (CAI). KomAushim, Faiyum; 21.9.1959; V. Täckholm s.n. (CAI). El-Faiyum, 28.5.1954; M. El Shafay s.n. (CAI). Kom Aushim, Faiyum, 29.9.1967; V. Täckholm, M. Imam, I. Elsayed \& M. El Mahdi s.n. (CAI). Kom Aushim, Faiyum, 21.9.1959; V. Täckholm s.n. (CAI). Kom Aushim,near Faiyum, ; Jan. 1953;Nabil El Hadidy s.n. (CAI). KomAushim, Faiyum, Fayoum; 15.7.1960; Loutfy Boulos s.n. (CAI). Wadi Wl. Rayan protected area herbarium, Fayoum; 1.2.2000; L.Boulos s.n. (CAI). Qasr Rashwan Tameyah, Fayoum, $\quad 29^{\circ} 27^{\prime} 30.4^{\prime \prime} \mathrm{N}, \quad 30^{\circ} 55^{\prime} 22.5 \mathrm{~F}$; 25.8.2017; M. Sayed, M. Faker \& F. Yousef (Fayium univ. Herbarium). Madinet Tameyah, Fayoum, 29²9'02.2"N, 3056'28.1"E; 25.8.2018; M. Sayed, M. Faker \& F. Yousef (Fayium univ. Herbarium). Ezbet El-Hariry, El-Rawda, Tameyah, Fayoum; 2927'38.8"N 3058'41.5"E, 25.8.2019; M. Sayed, M. Faker \& F. yousef (Fayium univ. Herbarium). Madinet Tameyah, Fayoum; 29²9'25.5"N, 3058'41.9"E; 25.8.2020; M. Sayed, M. Faker \& F. Yousef (Fayium univ. Herbarium). Kafr Al Maslat - Tamya, Fayoum,29³2'52.5"N 3058'55.9"E; 25.8.2021; M. Sayed, M. Faker \& F. Yousef (Fayium univ. Herbarium). Monshaat Doctor El-Gammal, Fayoum, 29³0'32.1"N 3103'21.3"E; 25.8.2022; M. Sayed, M. Faker \& F. Yousef (Fayium univ. Herbarium). Forqos, Tameyah, Fayoum,29²5'28.4"N, 3058'50.4" E; 25.8.2023; M. Sayed, M. Faker \& F. Yousef (Fayium univ. Herbarium). Al Gharq-Faiyum way Izbat Ad Daw, Minya, Etsa, Fayoum; 29¹2'44.4" N 3045'50.1"E; 16.9.2017; M. Sayed, M. Faker \& F. Yousef (Fayium univ. Herbarium). Madinat Al Fayoum - Tersa way -Naqalifah, Fayoum, $29^{\circ} 24$ '39.8" N 3049'31.9"E; 16.9.2018; M. Sayed, M. Faker \& F. Yousef (Fayium univ. Herbarium). Al Eelam Al Fayoum, Fayoum, 29¹9'38.2"N 3052'07.5"E;20.9.2017; M. Sayed, M. Faker
\& F. Yousef (Fayium univ. Herbarium). Damascus, Syria; 23.8.1959; Samir Ghabbour s.n. (CAI).

Flowering time: July- September

Distribution in Egypt: It has been reported from Nile Delta, Nile Vally, Oases of Siwa, Bahariya and Wadi Natrun, the Mediterranean coastal.

General distribution: Mediterranean area, S.W. Asia to N. Iran, S. Russia, Caucasus.

2. Cynanchum acutum subsp. sibiricum (Willd.) Rech. f, Fl. Iran. 73: 9. (1970).

Syn: Cynanchum sibiricum Willd. in Neue Schriften Ges. Naturf. Freunde Berlin 2: 124 (1799)

C. acutum L. var. longifolium (G.Martens) Ledeb., Fl. Ross. 3:548 (1847). Described from Siberia (holo. B-Willd. 5233, photo). The leaves one to triple as long as broad, up to $10 \times 3 \mathrm{~cm}$; broadly-cordata or narrowly sagittate; Basel lobes distinctly divergent concave sides (auriculate). Apex acute to long acuminate. Corona rarely short linguiformes; elongated appendages often lanceolate. Follicles $12.5-16 \mathrm{~cm}$.

\section{Representative specimens:}

Siwa Oasis; Meshanded 25Km West of Siwa; 26.10.1963; Loutfy Boulos; s.n. (CAI). Kom Aushim, Faiyum; Fayoum; 13.10.1967; V. Täckholm - M. Imam- N. El Hadidi; s.n. (CAI). El-Heiz, Tabliun, Baharia Oasis; 15.5.1978; Monier Abd El Ghani; 320 (CAI). Wadi Digla, Eastern Desert; 25.4.2006; M. Abdel Aleem; s.n. (CAI). El-Manair, 12 km from Ismaila on the desert road; 17.6.1980; Leg. A. Bakry; 1229(CAI). East of the Nile Delta/ El-Adlyah company for land reclamation; 14.9.1981; Leg. A. Bakry; 3175 (CAI). Ezbet EL Dleba, on gawsah drain: Hefna; El-Sharqia; 3.9.1953; N. El Hadidi; s.n. (CAI). Giza, Olive orchard; 16.11.2010; Bennoba, s.n. (CAI).

Flowering time: May-August.

Distribution in Egypt: Nile Delta, Siwa Oasis and Baharia Oasis

General distribution: Afghanistan, Kashmir, Kazakhstan, Mongolia, Pakistan, Russia, Turkmenistan; SW Asia.

-Cynanchum subgen. Mellichampia (New World)

Cynanchum subgen. Mellichampia (A. Gray) Woodson, Ann. Missouri Bot. Gard. 28: 209 
(1941).

Cynanchum sect. Mellichampia (A.Gray ex S. Watson) Sundell, Evol. Monogr. 5 (New World Sp. Cynanchum subgen. Mellichampia) 13 (1981): (1981).

\section{=Cynanchum laeve (Michx.) Pers.}

Syn. : Ampelamus albidus (Nutt.) Britton Enslenia albida Nutt. Gonolobus laevis Michx. Ampelamus laevis (Michx.) Krings

Herbaceous stem, twining, climbing with whitish sap, with villous hairy at stem margins. Petiolate, opposite leaves. Petioles up to $7 \mathrm{~cm}$ long, reddish-green. Glabrous blade, dark green with obvious veining top, typically cordate, to ovate, acute to apiculate or acuminate, up top $10 \mathrm{~cm}$ long and $8 \mathrm{~cm}$ broad. Inflorescence; Axillary umbellate cyme approximate 30 flowers, Peduncles up to $5 \mathrm{~cm}$, hairy. Pedicels up to $1 \mathrm{~cm}$ long, pubescent. Corolla intensely 5- whitish lobes, up to $7 \mathrm{~mm}$ long, and $3 \mathrm{~mm}$ broad, erect to patent, glabrous. Corona of 5 appendages. White appendages erect, up to $6 \mathrm{~mm}$ long, extended at base, 2 linear lobes pointed at apex. Calyx 5- green lobes, with nearly purple, ovate lanceolate, up to $3 \mathrm{~mm}$ long, sparse pubescent. Large follicle, up to $10-11 \mathrm{~cm}$ long and $4 \mathrm{~cm}$ wide at widest point, teardrop-shaped, glabrous. Winged seeds, up to $+8 \mathrm{~mm}$ long.

Flowering; July to September.

Habitat: Disturbed sites, railroads, roadsides, waste ground, along fences.

Distribution: Native to U.S.

Representative specimens: Prince George Co., Illinois, USA; 10.8.1939; L. B. Smith; R. P. underlin; Barcode:13667 (USF). Halifax Co., North Carolina, USA;19.7.1956; H. E. Ahles; R. P.underlin; Barcode:20265(USF). Jasper Co., Missouri, USA; 8.8.1920; E. J. Palmer; R. P. Wunderlin; Barcode:29684, (USF). Fairfax Co., Virginia, USA; 7.8.1910; P. Dowell; R. P. Wunderlin; Barcode:29685, (USF). Hamilton Co., Ohio, USA;7.8.1882; C. G. Lloyd; R. P. Wunderlin; Barcode:33754, (USF). Sharkey Co., Mississippi, USA;11.7.1955; J. D. Ray, Jr.; R. P. Wunderlin; Barcode:41111, (USF). Mercer Co.,Kentuchy,USA;23.7.1955;M. E. Wharton; R. P. Wunderlin; Barcode:43698, (USF). Union Co., Illinois, USA;23.8.1958; R. F. Thorne; R. P. Wunderlin; Barcode:53192,
(USF). Independence Co., Arkansas, USA;6.7.1968; R. D. Thomas; Barcode:86801, (USF). Macon Co., Tennessee, USA; 14.10.1968; K. E. Rogers; D. Drapalik; Barcode: 86937, (USF). Macon Co., Tennessee, USA; 14.10.1968; K. E. Rogers; D. Drapalik; Barcode: 94278, (USF). Cocke Co., Tennessee, USA; 29.7.1977; P. Genelle; Barcode: 95410, (USF).Lincoln Co., Missouri, USA; 10.8.1978; W. G. D'Arcy; B. Summers; Barcode: 214841, (USF).Westmoreland Co., Virginia, USA; 7.7.1990; T. R. Bradley; Barcode: 215064, (USF).Champaign Co., Illinois, USA; 10.8.2008;S. R. Hill; S. R. Hill;Barcode:277162, (USF).Jackson Co., Illinois, USA; 23.7.1998; S. R. Hill; S. R. Hill; Barcode: 283635, (USF). Wunderlin, et al., 2019. Atlas of Florida Plants (http://florida.plantatlas.usf.edu/).

\subsection{Morphometric analysis}

3.2.1. Testing variation in taxa and populations, using multivariate methods (Cluster analyses and ordination analyses)

After estimating how accurately the dendrograms represent the original Gower distance matrix, the cophenetic distances calculated from the NJ dendrogram $(r=0.83)$ while UPGMA representing $(\mathrm{r}=0.80)$. Consequently, the NJ topology is applied to the present study (Saitou \& Nei, 1987; Pankhurst 1991; Raff, 1966).

The NJ topology (Fig. 4) for multivariate analysis of 59 observation of 36 variables after removing lines with missing data. The relationship between studied taxa clarified at fan NJ, meanwhile, the most comparable leaf shapes and characters are on sister clades, and the most divergent cluster is insulated next to the root (Viscosi and Cardini 2011). However, the identified taxa of $C$. acutum subsp. sibiricum collected together at one node in the first cluster with some taxa from $C$. acutum subsp. acutum confirmed the more closely related between two subspecies. On the other hand, the second cluster gathered taxa from $C$. acutum subsp. acutum and $C$. laeve to show the relation and the similarity between two species.

PCA biplot (Fig. 5) showed a total variation $37.7 \%$ at first PC1 axis and $8.9 \%$ at second PC2, both designated the highest and moderate linkage and relationships between 


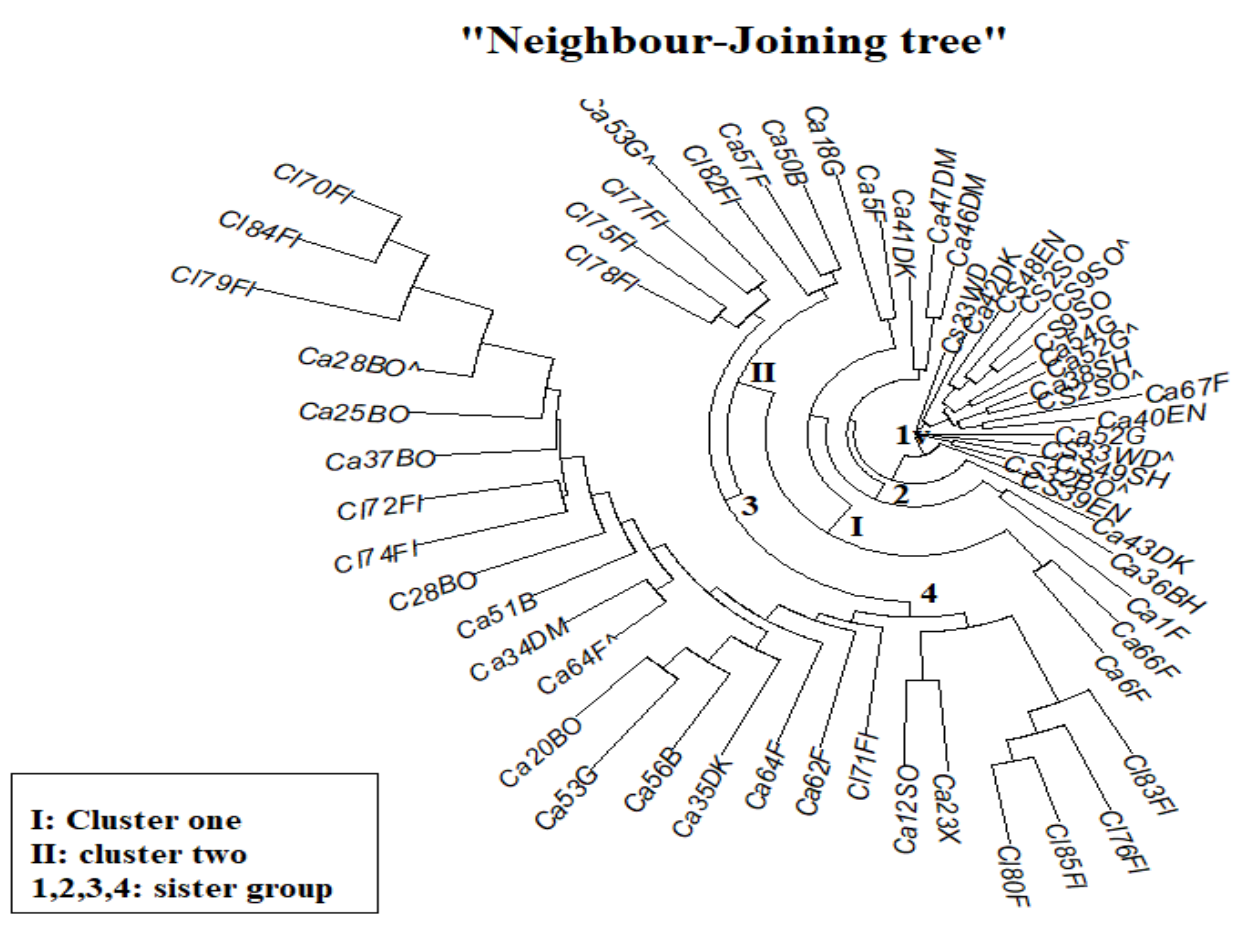

Fig. 4. Fan Neighbour-Joining tree for multivariate analysis of 59 observation of 36 variables.

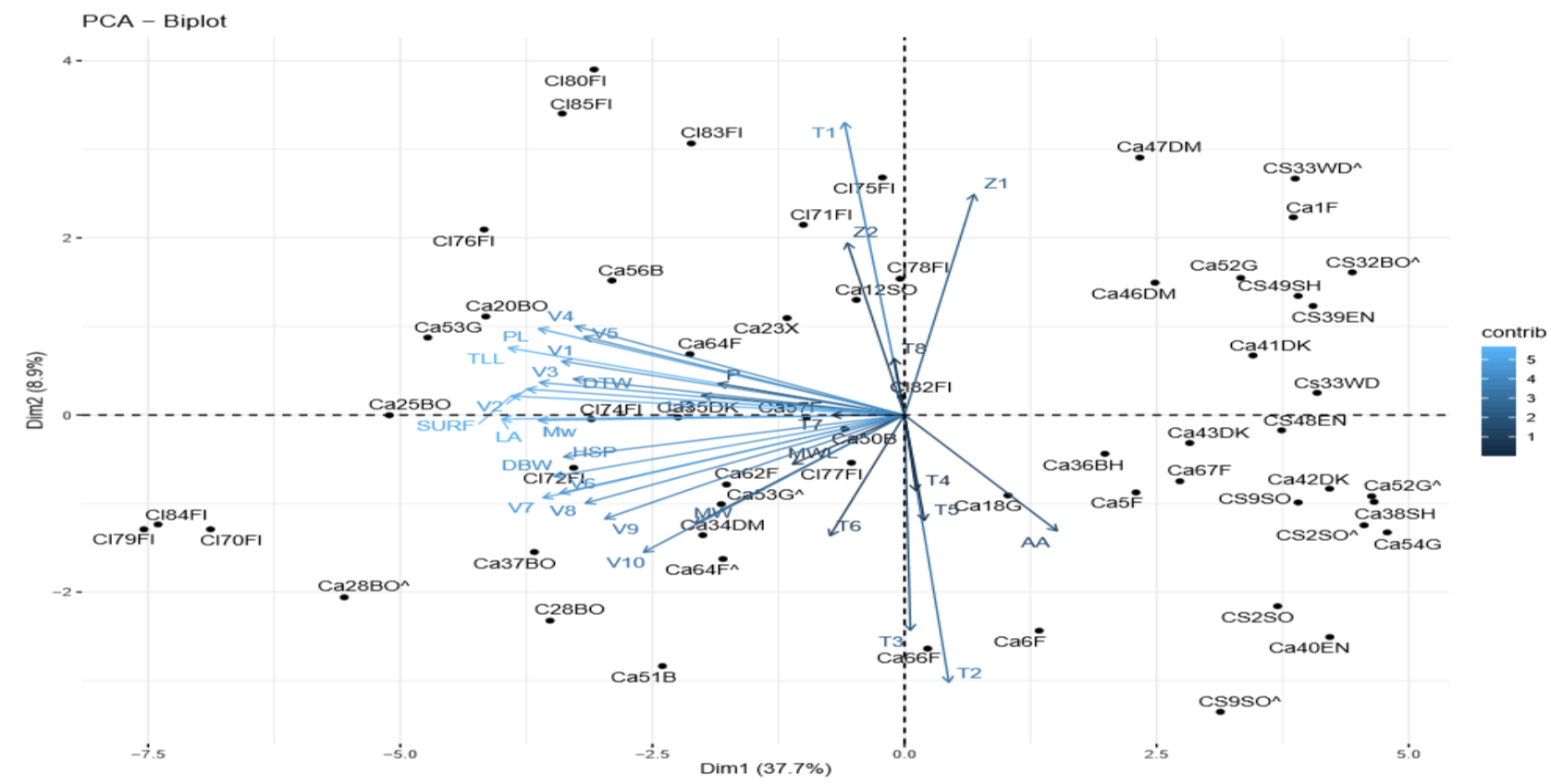

Fig.5. PCA biplot with total variation $37.7 \%$ for first PC1 axis separate C. acutum subsp. sibiricum and C. acutum subsp. acutum from larger leaf C. acutum subsp. acutum and C. laeve. Total variation $8.9 \%$ for second PC2 separate leaf C. acutum subsp. acutum and $C$. laeve according to the measurements of medium width and maximum width length. 
examined taxa and also among the population from same taxa.

\subsubsection{Testing variation in taxa and populations, using a modified Procrustes ANOVA}

Results of the statistical estimation of variance in ANOVA and MANOVA, demonstrated in Table 3 and showed significant $(\mathrm{P}<0.05)$ differences in leaf traits between three taxa (C. acutum subsp. acutum, $C$.

acutum subsp. sibiricum and $C$. laeve). This result is also obviously seen in the Box-plot and CVA.

\subsection{Testing taxa differences using permutation tests and discriminant analyses}

The box-plot collecting all leaf traits (Fig. 6.9) shows that $C$. laeve tends to be slightly larger than C. acutum subsp. acutum and $C$. acutum subsp. sibiricum, but there is a lot of overlap between the populations. While the box plots for some leaf traits like Total leaf length, petiole length, width length, maximum width length, leaf surface and leaf area (Fig.6.2-6.8) showed large variation at interquartile range and median that confirm the separation of three taxa under studied.

Canonical variate analysis showed a significant difference between taxa $\left(P=0.001^{* * *}\right)$, where the first discriminating axis of canonical variate analysis (CVA) separated $C$. laeve from two $C$. acutum subspecies expect few specimens from $C$. acutum subsp. acutum to indicate the relation between the two taxa with a total variation $83 \%$. The second discriminating the axis isolated C. acutum subsp. sibiricum specimens at the top of biplot from relative $C$. acutum subsp. acutum to total variation of $67 \%$ (Fig. 7). By using Discriminant analysis, check the total variation between $C$. acutum subsp. acutum and C. acutum subsp. sibiricum (77\%) then between C. acutum subsp. acutum and $C$. laeve to show $86 \%$ of the variation and significant value $\left(P=0.002^{* *}\right)$ (Fig. 8).

\section{Discussion}

Cynanchum acutum is distributed in worldwide. It occurs in wet soils and nearby to freshwater, roadsides, wastelands, and gardens. It ranked as Least Concern (Akhani 2014).

The present study agrees with Rechinger, (1970) who stated that "The difference between two subspecies $C$. acutum is easy about extreme traits, but mainly problematic because the exploiting characteristics are not fixedly correlated with characteristics of leaf". Accordingly, the study going to use the modern method like Computerized geometric Morphometric analysis to a good distinction between them by selecting more viable characters to help the differentiation between taxa, depending mainly on quantitative measurement, test and visualize a digital image to identify the differences in form in extremely actual perfect and, statically powerful way (Viscosi and Cardini 2011; Cope et al. 2012; Mayer et al. 2014; López De Heredia et al. 2017 ; Klein \& Svoboda 2017).

This close relationship between examined taxa appear at NJ topology and PCA biplot, Owing to the variables at the shape and size of leaves between individuals and different populations. However, the first cluster has individuals of $C$. acutum subsp. acutum and $C$.

acutum subsp. sibiricum, which separated out to two sister groups, the first one collects all identified $C$. acutum subsp. sibiricum with the closeness of it from C. acutum subsp. acutum, that showed the slightly distinction between two subspecies with and approve that the main difference is the shape and base lobe of leaf show it in, display the leaf shape of hastate-cordate, the base of lobes to be auriculate or hastate, and the basal lobes distinctly divergent are the obvious characters for C. acutum subsp. sibiricum (Davis 1978; Rechinger 1970; Gilbert et al. 1995; Li et al. 1995; Boulos 2000).

The second sister group at cluster I has typically $C$. acutum subsp. acutum, which have a cordate leaf with cordate or broadly auriculate leaf base and the basal lobes scarcely divergent (Davis 1978; Boulos 2000). Whereas the second cluster II assembly two different species (C. acutum subsp. acutum and $C$. laeve) which contain typically cordate and broadly cordate leaves, maximum width 


\section{Faten Y. Ellmouni}

Table 3.1. Hierarchical sum of squares ANOVA of three examined taxa. SS = sum of squares, MS = mean sum of squares (i.e., SS divided by $\mathrm{df}$ ) and $\mathrm{df}=$ degree of freedom.

\begin{tabular}{|c|c|c|c|c|c|}
\hline & SS & MS & df & F value & $\operatorname{Pr}(>F)$ \\
\hline Taxon & 55762062 & 18587354 & 3 & 2626 & $<2 \mathrm{e}-16 * * *$ \\
\hline Residuals & 424772 & 7080 & 60 & & \\
\hline Population & 55834218 & 4294940 & 13 & 609 & $<2 \mathrm{e}-16 * * *$ \\
\hline Residuals & 352616 & 7052 & 50 & & \\
\hline
\end{tabular}

Table 3.2. MANOVA test of three examined taxa. SS = sum of squares, MS = mean sum of squares (i.e., SS divided by $\mathrm{df}$ ) and $\mathrm{df}=$ degree of freedom.

\begin{tabular}{|c|c|c|c|c|c|c|}
\hline & Df & Pillais trace & Approx. F & num Df & den Df & $\operatorname{Pr}(>F)$ \\
\hline Taxon & 3 & 2.5215 & 4.2157 & 105 & 84 & $3.926 \mathrm{e}-11 * * *$ \\
\hline Residuals & 60 & & & & & \\
\hline Population & 13 & 8.1421 & 1.3408 & 455 & 364 & $0.001735 * *$ \\
\hline Residuals & 50 & & & & & \\
\hline
\end{tabular}
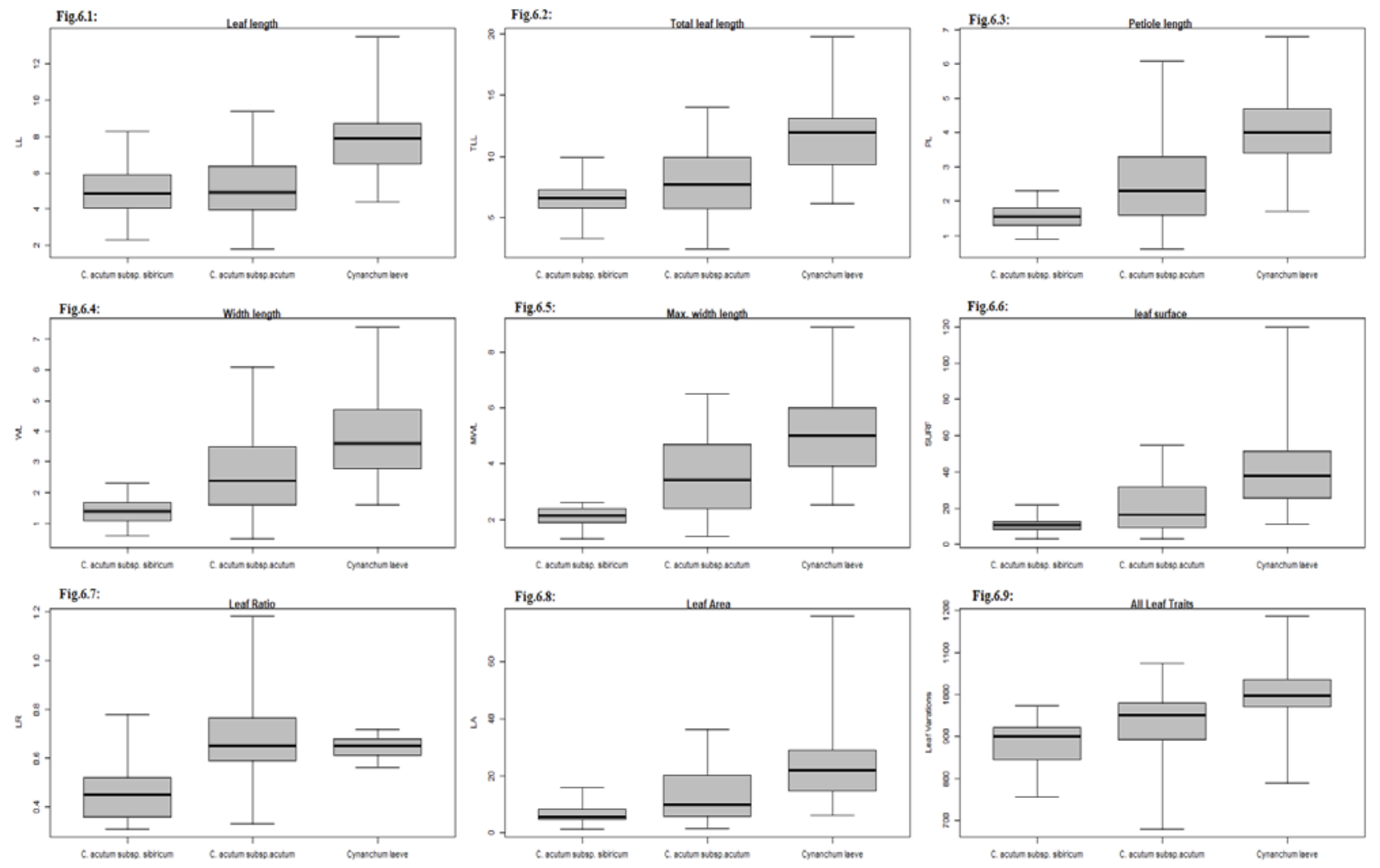

Fig.6. The box-plot of three examined taxa, depending on all leaf traits and selecting some of them showed that $C$. laeve tend to be slightly larger than C. acutum subsp. acutum and C. acutum subsp. sibiricum, with overlaps between the populations. 


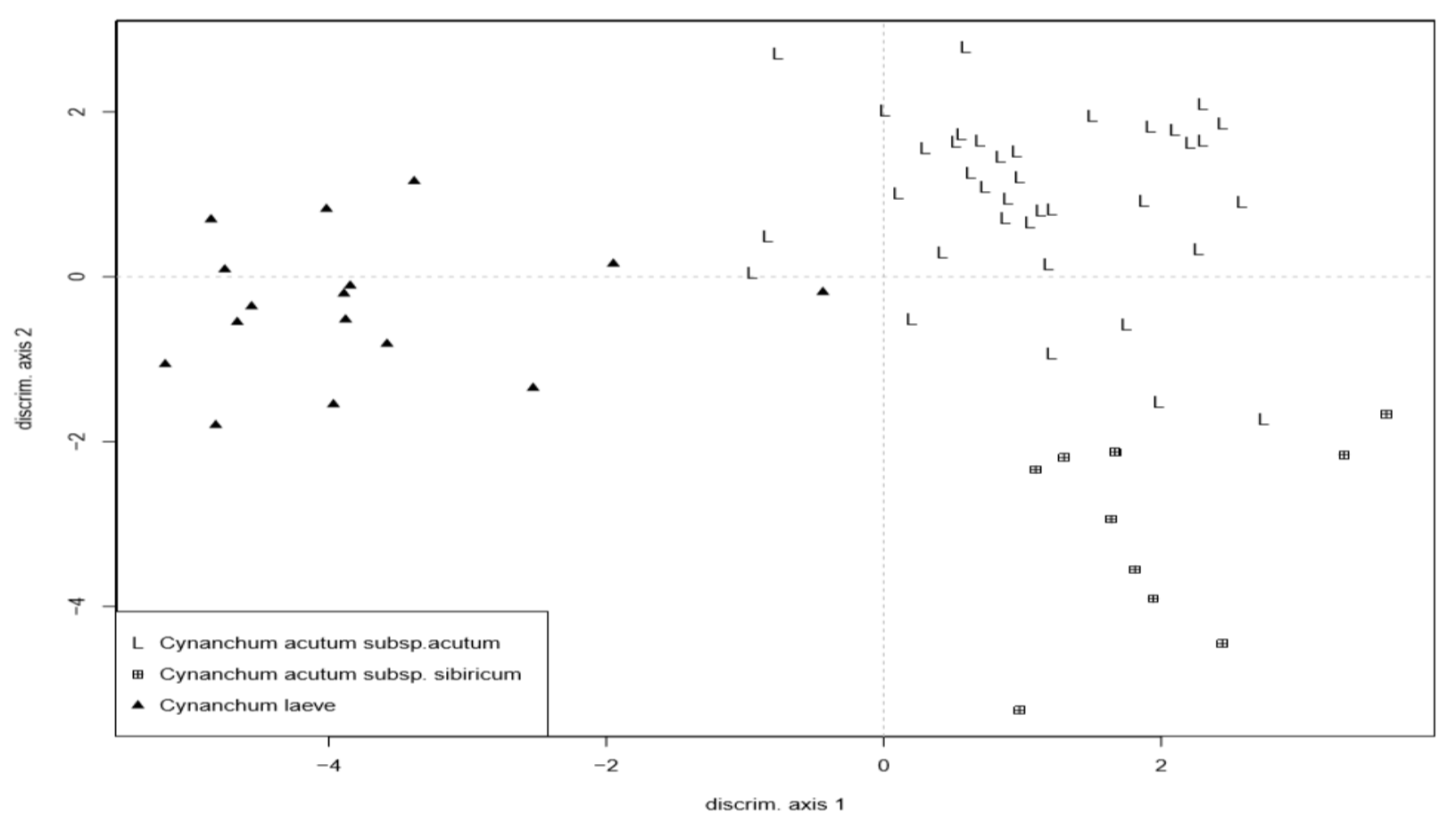

Fig.7. canonical variate analysis (CVA) for three taxa, which ranged in CCA1 and CCA2 as for C. laeve (-3.76 and -0.34), C. acutum subsp. acutum (1.096 and 0.97), and C. acutum subsp. sibiricum (1.98 and -3.05$)$
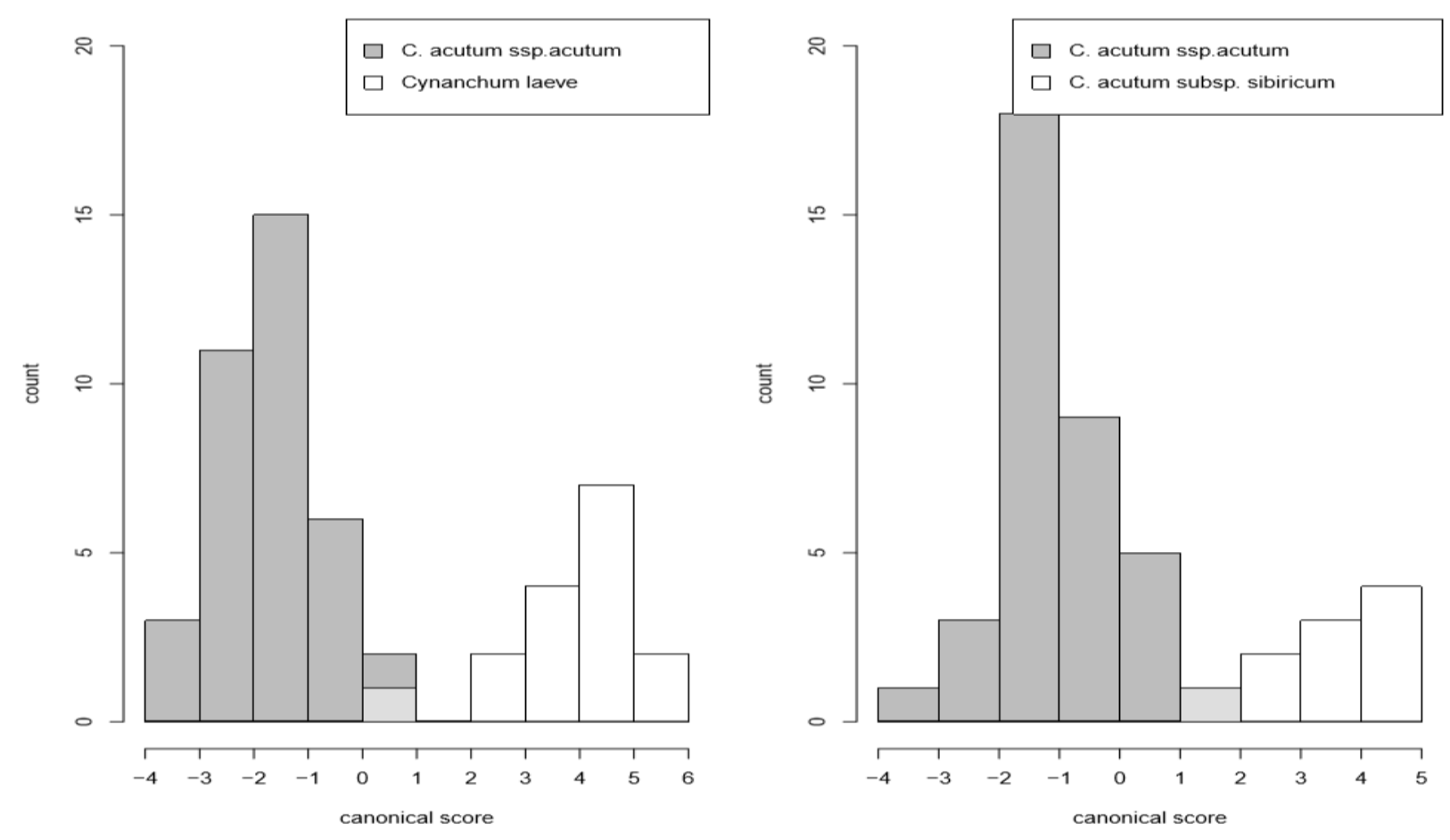

Fig.8. Discriminant analysis, in left histogram for $C$. acutum subsp. acutum and $C$. laeve and the right histogram C. acutum subsp. acutum and C. acutum subsp. sibiricum, the both point to the variance between taxa. 
length ranged between (3-8 cm) and maximum petiole length ranged between $(2.3-6 \mathrm{~cm})$.

The main reason for chosen of $C$. laeve to be outgroup in the current study that is more resemblance species to C. acutum and also belong to different section according to Liede \& Kunze (2002). The results displayed a relative relationship between the old world Cynanchum presented by C. acutum subsp. acutum and New World Cynanchum (Cynanchum laeve), was confirmed before by Liede \& Tauber (2002) who used cpDNA spacers to analyze a lot of memberships of sections of Cynanchum and found that $C$. laeve subgen. Mellichampia is correctly placed under Cynanchum and formed a sister clade to each other. And they also suggested using the vegetative character were being good sign than floral characters as doing in this study.

While the multivariate analysis demonstrations the relationship and confusion between taxa the Box-plot, canonical variate analysis CVA and discriminant analyses (DA) confirmed separation of each three taxa with a few overlaps. The discriminant analyses revealed to the percent of medium width is the main trait that can distinguish the two subspecies with $39 \%$ variation depending on Mw\%.

That for the aim of this study about the presence of two subspecies at Egypt according to the Herbarium sheet kept at (CAI) has been confirmed by different methods either via classical taxonomy or by modern taxonomy (GMM). The current study agreed and recommended the using of Modern Geometric Morphometric Analysis, however, is very potential for applying, a relatively highly effective, accurate and viable tool to characterization and classification between closely related taxa (Viscosi and Cardini 2011; Vieira et al. (2014).; Lo Bianco and Mirabella 2018). In line with the finding of Viscosi and Cardini 2011 stated that "Taxonomists must be definitely keen on taking improvement for new quantitative methods for the description of taxa including semi-automated computerized tools".

\section{Conclusion}

The study aimed to revise Cynanchum acutum in Egypt and their relative subspecies by using classical taxonomy and modern geometric morphometric analysis. After extensive studies at the samples of the Herbarium sheet kept at (CAI) and study the description of $C$. acutum subspecies in different flora, the present study confirms of existence C. acutum subsp. sibiricum in Egypt. The morphometric analysis going to the same trend with classical taxonomy where $\mathrm{NJ}$ and PCA exhibited the relationship between taxa understudy to reveal the relation between two (C. acutum subsp. acutum and $C$. acutum subsp. sibiricum) and (C. acutum subsp. acutum and Cynanchum laeve). Finally, Boxplot, CVA and DA confirmed the separation of the taxa. This study clarifies the situation of Cynanchum acutum in Egypt and the concluded and confirmed the presence of two subspecies viz.: subsp. acutum and subsp. sibiricum, and recommended using the geometric modern analysis as a practical method of classification.

\section{Acknowledgments}

The author is greatly appreciative to the staff of Cairo University Herbarium (CAI) for facilities provided.

\section{References}

Akhani, H. (2014). Cynanchum acutum. The IUCN Red List of Threatened Species 2014: e.T19181578A21248535.

Alvarez Cruz, N.S. \& Schmelzer, G.H., (2012). Cynanchum viminale (L.) L. In: Schmelzer, G.H. \& Gurib-Fakim, A. (Editors). Prota 11(2): Medicinal plants/Plantes médicinales 2. PROTA, Wageningen, Netherlands.

Aykut, Y., Emel, U., \& Tekin, B. M. (2017). Morphological variability of evergreen oaks (Quercus) in Turkey. Bangladesh Journal of Plant Taxonomy, 24(1), 39-47.

Baláš, M., Kuneš, I., Gallo, J., \& Rašáková, N. (2016). Review on Betula oycoviensis and foliar morphometry of the species in Volyně, Czech Republic. Dendrobiology, 76, 117-125. Bell A, Bryan A (2008) Plant Form: An Illustrated Guide to Flowering Plant Morphology. London: Timber Press. 432 p.

Boulos L (1995) Flora of Egypt, Checklist. El Hadara Publishing, Cairo, Egypt

Boulos L (2000) Flora of Egypt. Vol. 2 (Geraniaceae - Boraginaceae). Al Hadara publishing, Cairo, Egypt. 
Cope, J. S., Corney, D., Clark, J. Y., Remagnino, P., and Wilkin, P. (2012). Plant species identification using digital morphometrics: a review. Expert Syst. Appl. 39 , 7562-7573. doi: 10.1016/j.eswa.2012.01.073

Davis, P.H. 1978.Miller in: P.H.Davis (ed.), Flora of Turkey, vol.6 p.166-167

Effat, H. A., \& El-Zeiny, A. (2017). Modeling potential zones for solar energy in Fayoum, Egypt, using satellite and spatial data. Modeling Earth Systems and Environment, 3(4), 1529-1542

Endress, P. K. 2016. Development and evolution of extreme synorganization in angiosperm flowers and diversity: a comparison of Apocynaceae and Orchidaceae. Annals of Botany 117: 749-767.

Forster, P. I. (1991). A taxonomic revision of Cynanchum L. (Asclepiadaceae: Asclepiadoideae) in Australia. Austrobaileya, 443-466.

Gilbert, M.G., Stevens, W.D. \& Li, P.T. 1995. Notes on the Asclepiadaceae of China. Novon 5: 1-16. http://dx.doi.org/10.2307/3391820

Goyder, D., A. Nicholas and S. LiedeSchumann. 2007. Phylogenetic relationships in subtribe Asclepiadinae (Apocynaceae: Asclepiadoideae). Annals of the Missouri Botanical Garden 94: 423-434

Greuter, W., \& Raus, T. (1984). MedChecklist Notulae, 9. Willdenowia, 37-54.

Kassambara, A. (2017). Practical guide to cluster analysis in $R$ : Unsupervised machine learning (Vol. 1). STHDA.

Khanum, R., Surveswaran, S., Meve, U., \& Liede-Schumann, S. (2016). Cynanchum (Apocynaceae: Asclepiadoideae): a pantropical Asclepiadoideae genus revisited. Taxon, 65(3), 467-486.

Klein, L. L., \& Svoboda, H. T. (2017). Comprehensive methods for leaf geometric morphometric analyses. Bio-protocol, 7, e2269

Koutecký P. (2015). MorphoTools: a set of R functions for morphometric analysis. - Plant Systematics and Evolution 301: 1115-1121; doi 10.1007/s00606-014-1153-2

Li, P.T., Gilbert, M.G. \& Stevens, W.D. 1995. Asclepiadaceae. Pp. 189-270 in: $\mathrm{Wu}$,
C.Y. \& Raven, P.H. (eds.), Flora of China, vol. 16. Beijing: Science Press; St. Louis: Missouri Botanical Garden Press.

Liede, S. (1997). American Cynanchum (Asclepiadaceae): A Preliminary Infrageneric Classification. Novon, 172-181.

Liede, S. (1999). The genera Cynanchum and Vincetoxicum. Blumea, 44(2), 471-495.

Liede, S., \& Kunze, H. (2002). Cynanchum and the Cynanchinae (ApocynaceaeAsclepiadoideae): a molecular, anatomical and latex triterpenoid study. Organisms Diversity \& Evolution, 2(3), 239-269.

Liede, S., \& Täuber, A. (2002). Circumscription of the genus Cynanchum (Apocynaceae-Asclepiadoideae). Systematic Botany, 789-800.

Liu, Y., Li, Y., Song, J., Zhang, R., Yan, Y., Wang, Y., \& Du, F. K. (2018). Geometric morphometric analyses of leaf shapes in two sympatric Chinese oaks: Quercus dentata Thunberg and Quercus aliena Blume (Fagaceae). Annals of Forest Science, 75(4), 90.

Lo Bianco, R., \& Mirabella, F. (2018). Use of Leaf and Fruit Morphometric Analysis to Identify and Classify White Mulberry (Morus alba L.) Genotypes. Agriculture, 8(10), 157.

López De Heredia, U., Duro-García, M. J., \& Soto, Á. (2018). Leaf morphology of progenies in Q. suber, Q. ilex, and their hybrids using multivariate and geometric morphometric analysis. iForestBiogeosciences and Forestry, 11(1), 90

Mayer C, Metscher BD, Müller GB, Mitteroecker P (2014). Studying Developmental Variation with Geometric Morphometric Image Analysis (GMIA). PLoS ONE 9(12): e115076. https://doi.org/10.1371/journal.pone.0115076 Nam, B. M., \& Chung, G. Y. (2018). Taxonomic implications of floral morphology in the subfamily Asclepiadoideae (Apocynaceae sl) in Korea. Korean Journal of Plant Taxonomy, 48(3), 172-184.

Quattrocchi, U. 2000 CRC world dictionary of plant names: common names, scientific names, eponyms, synonyms, and etymology. Routledge. Volume I A-C

R Development Core Team. 2016. R: A language and environment for statistical computer. R Foundation for Statistical 
Computing, Vienna, Austria. Website http://www.R-project.org/.

Rapini, A., C. van den Berg and S. LiedeShumann. 2007. Diversification of Asclepiadoideae (Apocynaceae) in the New World. Annals of the Missouri Botanical Garden 94: 407-422.

Rasband, W.S., 1997-2018. ImageJ, U. S. National Institutes of Health, Bethesda, Maryland, USA, https://imagej.nih.gov/ij/,

Rechinger K. H. (ed.) (1970). Flora Iranica, No. 1- 177. Asclepiadaceae: 8-9 Akademische Durck-U. Verlagsanstalt, Graz.

Täckholm V (1974) Students' Flora of Egypt: second edition. Cairo University, Cairo.

Vieira, M., Mayo, S. J., \& de Andrade, I. M. (2014). Geometric morphometrics of leaves of Anacardium microcarpum Ducke and A. occidentale L. (Anacardiaceae) from the coastal region of Piauí, Brazil. Brazilian Journal of Botany, 37(3), 315-327.

Viscosi V, Cardini A (2011) Leaf Morphology, Taxonomy and Geometric Morphometrics: A Simplified Protocol for Beginners. PLoS ONE 6(10): e25630. doi:10.1371/journal.pone.0025630

Wunderlin, R. P., B. F. Hansen, A. R. Franck, and F. B. Essig. (2019). Atlas of Florida

Plants (http://florida.plantatlas.usf.edu/).

[S. M. Landry and K. N. Campbell (application development), USF Water Institute.] Institute for Systematic Botany, University of South Florida, Tampa.

Zahidi A, Bani-Aameur F, El Mousadik A (2013) Variability in leaf size and shape in three natural populations of Argania spinosa (L.) Skeels. International Journal of Current Research and Academic Review 1:13-25 


\section{Geometric morphometrics of leaves of Cynanchum acutum $\mathrm{L}$.}

Supplementary 1: The distribution of the monitored Cynanchum acutum subsp. acutum in Fayoum depression during summer 2017, collected by M. Sayed, M. Faker \& F. Yousef (Fayium University Herbarium).

\begin{tabular}{|c|c|c|c|c|}
\hline Site & Locality & Latitude & Longitude & $\begin{array}{c}\text { date of } \\
\text { collected }\end{array}$ \\
\hline 1 & $\begin{array}{l}\text { Madinet Senouris, Ezbet Mohammed Mahfouz, Senoures, Faiyum } \\
\text { Governorate }\end{array}$ & $29^{\circ} 26^{\prime} 08.3 " \mathrm{~N}$ & $30^{\circ} 53^{\prime} 03.4 " \mathrm{E}$ & 25.8.2017 \\
\hline 2 & Qasr Rashwan,Tameyah, Faiyum Governorate & $29^{\circ} 27^{\prime} 30.4^{\prime \prime} \mathrm{N}$ & $30^{\circ} 55^{\prime} 22.5 " \mathrm{E}$ & 25.8.2017 \\
\hline 3 & Madinet Tameyah, Tameyah & $29^{\circ} 29^{\prime} 02.2^{\prime \prime} \mathrm{N}$ & $30^{\circ} 56^{\prime} 28.1 " \mathrm{E}$ & 25.8.2017 \\
\hline 4 & Ezbet El-Hariry, El-Rawda, Tameyah & $2927 ' 38.8 " \mathrm{~N}$ & $30^{\circ} 58^{\prime} 41.5^{\prime \prime} \mathrm{E}$ & 25.8.2017 \\
\hline 5 & Madinet Tameyah, Tameyah, Faiyum & $29^{\circ} 29^{\prime} 25.5^{\prime \prime} \mathrm{N}$ & $30^{\circ} 58^{\prime} 41.9 " \mathrm{E}$ & 25.8.2017 \\
\hline 6 & Kafr Al Maslat - Tamya,Fanous, Tameyah, Faiyum Govern & $29^{\circ} 32^{\prime} 52.5 " \mathrm{~N}$ & $30^{\circ} 58^{\prime} 55.9 " \mathrm{E}$ & 25.8.2017 \\
\hline 7 & Monshaat Doctor El-Gammal,Tameyah, Faiyum Governorate & $29^{\circ} 30^{\prime} 32.1 " \mathrm{~N}$ & $31^{\circ} 03^{\prime} 21.3^{\prime \prime} \mathrm{E}$ & 25.8.2017 \\
\hline 8 & Forqos, Tameyah, Faiyum Govern & $29^{\circ} 25^{\prime} 28.4 " \mathrm{~N}$ & $30^{\circ} 58^{\prime} 50.4 " \mathrm{E}$ & 25.8.2017 \\
\hline 9 & Qasr Bayad,Ibsheway, Faiyum Governorate & $29^{\circ} 21^{\prime} 30.2^{\prime \prime} \mathrm{N}$ & $30^{\circ} 44^{\prime} 12.1 " \mathrm{E}$ & 12.9.2017 \\
\hline 10 & Kahk, Youssef El Seddik, Faiyum Governora & $29^{\circ} 26^{\prime} 02.0^{\prime \prime} \mathrm{N}$ & 30³8'39.4"Е & 12.9.2017 \\
\hline 11 & An Nazlah, Youssef El Seddik, Faiyum Gove & $29^{\circ} 17^{\prime} 59.8^{\prime \prime} \mathrm{N}$ & 30³8'14.4"E & 12.9.2017 \\
\hline 12 & Al Hamouli,Youssef El Seddik, Faiyum Governorate & $29^{\circ} 17^{\prime} 10^{\prime \prime} \mathrm{N}$ & $30^{\circ} 37^{\prime} 15.4^{\prime \prime} \mathrm{E}$ & 12.9.2017 \\
\hline 13 & Al Agameyin-Ibsheway way,Zaid, Ibsheway, Faiyum Governorate & $29^{\circ} 20^{\prime} 57.9^{\prime \prime} \mathrm{N}$ & $30^{\circ} 41^{\prime} 26.0 " \mathrm{E}$ & 12.9.2017 \\
\hline 14 & $\begin{array}{l}\text { Madinat Al Fayoum - Tohbar way, Al Agameyin,Ibsheway, Faiyum } \\
\text { Governorate }\end{array}$ & $29^{\circ} 19^{\prime} 48.2^{\prime \prime} \mathrm{N}$ & $30^{\circ} 42^{\prime} 58.6^{\prime \prime} \mathrm{E}$ & 12.9.2017 \\
\hline 15 & Al Gaafra - Minya Al Hayt,Minya, ATSA, Faiyum Governorate, & $29^{\circ} 13 ' 32.8^{\prime \prime} \mathrm{N}$ & $30^{\circ} 45^{\prime} 29.5 " \mathrm{E}$ & 16.9.2017 \\
\hline 16 & Al Gharq-Faiyum way,Izbat Ad Daw, Minya, ATSA & $29^{\circ} 12^{\prime} 44.4^{\prime \prime} \mathrm{N}$ & $30^{\circ} 45^{\prime} 50.1 \mathrm{E} \mathrm{E}$ & 16.9.2017 \\
\hline 17 & Ezbet Ali Farag - Al Hadqa,Al Hadeqah, Al Fayoum, Faiyum Governorate & $29^{\circ} 16$ '2.9" N & $30^{\circ} 50^{\prime} 42.5 " \mathrm{E}$ & 16.9.2017 \\
\hline 18 & Hawaret Al Maqtaa,Al Fayoum, Faiyum Governorate & $29^{\circ} 14$ '50.7" N & $30^{\circ} 54^{\prime} 29.5 " \mathrm{E}$ & 16.9.2017 \\
\hline 19 & Madinat Al Fayoum - Kafr Mahzooz way,Matar Tares, Senoures, Faiyum Go & $29^{\circ} 22$ '46.1" N & $30^{\circ} 54^{\prime} 17.1 " \mathrm{E}$ & 16.9.2017 \\
\hline 20 & Behmo, Senoures, Faiyum Govern & $29^{\circ} 22$ '27.1" N & $30^{\circ} 50^{\prime} 51.4 \mathrm{E}$ & 16.9.2017 \\
\hline 21 & Madinat Al Fayoum - Tersa way,Naqalifah & $29^{\circ} 24$ '39.8" N & $30^{\circ} 49^{\prime} 31.9 " \mathrm{E}$ & 16.9.2017 \\
\hline 22 & Senoures, Faiyum Governorate & $29^{\circ} 17$ '21.78" N & $30^{\circ} 52^{\prime} 52.7^{\prime \prime E}$ & 16.9.2017 \\
\hline 23 & Kofour an Nil,Al Fayoum, Faiyum Governorate & $29^{\circ} 18^{\prime} 46.63 " \mathrm{~N}$ & $30^{\circ} 53^{\prime 2} 23.14 " \mathrm{E}$ & 20.9.2017 \\
\hline 24 & Al Edwah, Al Fayoum, Faiyum Gov & $29^{\circ} 19$ '58.7" N & $30^{\circ} 55^{\prime} 52 " \mathrm{E}$ & 20.9.2017 \\
\hline 25 & Al Eelam,Al Fayoum, Faiyum Governorate & $29^{\circ} 19^{\prime} 38.2^{\prime \prime} \mathrm{N}$ & $30^{\circ} 52^{\prime} 07.5 \mathrm{E}$ & 20.9.2017 \\
\hline 26 & Zawyet Al Kerdaseya,Bani Saleh, Al Fayoum, Faiyum Gov & $29^{\circ} 21^{\prime} 18.8^{\prime \prime} \mathrm{N}$ & $30^{\circ} 48^{\prime} 18.9^{\prime \prime} \mathrm{E}$ & 20.9.2017 \\
\hline
\end{tabular}

Supplementary 2: Details about Cynanchum specimen used in present study.

\begin{tabular}{|c|c|c|}
\hline code & & Locality \\
\hline Ca1 F & $\mathrm{Nv}$ & Fayoum, KomAushim, Faiyum, 21.9.1959; V. Täckholm; 6029(CAI). \\
\hline Cs2 SW & $\mathrm{O}$ & Siwa Oasis, Meshanded 25Km West of Siwa, 26.10.1963; L. Boulos, 6023(CAI). \\
\hline Ca3 SW & $\mathrm{O}$ & Siwa Oasis, Meshanded 25Km West of Siwa, 26.10.1963; Loutfy Boulos, 6024(CAI). \\
\hline $\mathrm{Ca} 4 \mathrm{Alx}$ & M & Faculty of agriculture, farms, Alexandria; 28.8.1953; Loutfy Boulos, 6008(CAI). \\
\hline Ca5 F & $\mathrm{Nv}$ & Fayoum, El-Faiyum, 28.5.1954, M. El Shafay, 6034(CAI). \\
\hline $\mathrm{Ca} 6 \mathrm{~F}$ & Nv & Fayoum, El-Faiyum, 28.5.1954, M. El Shafay, 6026(CAI). \\
\hline $\mathrm{Ca} 7 \mathrm{~F}$ & Nv & Fayoum, KomAushim, Faiyum, 29.9.1967; V. Täckholm - M. Imam - I. Elsayed- M. El Mahdi; 6036(CAI). \\
\hline $\mathrm{Ca} 8 \mathrm{~F}$ & Nv & Fayoum, KomAushim, Faiyum, 13.10.1967; V. Täckholm - M. Imam- N. El Hadidy; 6035(CAI). \\
\hline Cs9 SW & $\mathrm{O}$ & Siwa Oasis, Siwa oasis/ Abu Sharour, 1.4.1968, Gun Pomeé- and Nabil El Hadidy;6021(CAI). \\
\hline Ca10 F & Nv & Fayoum, KomAushim, Faiyum, 21.9.1959; Vivi Täckholm; 6032(CAI). \\
\hline Ca11 B & Nv & Beheira, Beheira province, Rosetta, 16.7.1987; Alaa Amer, 11904(CAI). \\
\hline Ca12 SW & $\mathrm{O}$ & Siwa Oasis, 27.12.1969 ; M. A. Zahran / L. Boulos, 6020(CAI). \\
\hline Ca13 F & $\mathrm{Nv}$ & Fayoum, Kom Osheem, near Faiyum, Jan. 1953; Nabil El Hadidy 6025(CAI). \\
\hline $\mathrm{Ca} 14 \mathrm{~F}$ & Nv & Fayoum, Kom Osheem, near Faiyum, Jan. 1953; Nabil El Hadidy 6028(CAI). \\
\hline Ca15 F & $\mathrm{Nv}$ & Fayoum, KomAushim, Faiyum, 15.7.1960; Loutfy Boulos 6027(CAI). \\
\hline Ca16 GZ & $\mathrm{Nv}$ & Giza, Giza near Cairo, 19.10.1910; Ernst Hartmann 6016(CAI). \\
\hline Ca17 ALX & M & Alex, Faculty of agriculture farm, Alexandria Univ., 28.8.1952; Nabil El Hadidy 6009(CAI). \\
\hline Ca18 GZ & $\mathrm{Nv}$ & Giza, Orman Gardens, Giza, 6.10.1954; Soliman Sisi, 6011(CAI). \\
\hline Ca19 GZ & $\mathrm{Nv}$ & Giza, Orman Gardens, Giza, 6.10.1954; Soliman Sisi, 6013(CAI). \\
\hline $\mathrm{Ca} 20 \mathrm{BO}$ & $\mathrm{O}$ & Baharia Oasis, Baharia Oasis, Zabou, 11.9.1971; M. Imam, 5987(CAI). \\
\hline
\end{tabular}




\section{Faten Y. Ellmouni}

\begin{tabular}{|c|c|c|}
\hline Ca21 DK & Nv & Dakahlia, Dakahlia- Aga, 11.10.1929; Elhamy Greiss, 5968(CAI). \\
\hline Ca22 DM & $\mathrm{Nv}$ & Demietta, Between Ras el Bar and Demietta, 13.9.1929; M.T. Hefnawy, 5980(CAI). \\
\hline Ca23 ALX & M & $\begin{array}{l}\text { Alex, Masraf El Gabaroti, El Aslah Mohatta, on the road Alexandria-Rosetta, 18.9.1970; Imam, Ibrahim, Mahdi } \\
\text { 5986(CAI). }\end{array}$ \\
\hline Ca24 DM & Nv & Demietta, Between Ras el Bar and Demietta, 13.9.1929, M.T. Hefnawy, 5978(CAI). \\
\hline Ca25 BO & $\mathrm{O}$ & Baharia Oasis, Al-Zabw, 4.10.1978; Monier Abd El Ghani, 677(CAI). \\
\hline $\mathrm{Ca} 26 \mathrm{BO}$ & $\mathrm{O}$ & Baharia Oasis, Al-Harra, Ain Boulol, on walls \& hedges, 24.10.1979; Monier Abd El Ghani , 2112(CAI). \\
\hline $\mathrm{Ca} 27 \mathrm{BO}$ & $\mathrm{O}$ & Baharia Oasis, Al-Zabw, 18.7.1978; Monier Abd El Ghani, 490(CAI). \\
\hline $\mathrm{Ca} 28 \mathrm{BO}$ & $\mathrm{O}$ & Baharia Oasis, Al-Harra, Ain Boulol, on fences, 24.10.1979; Monier Abd El Ghani, 2112(CAI). \\
\hline $\mathrm{Ca} 29 \mathrm{BH}$ & Nv & Beheira, 8-Mar-08, G. Maire, 5970(CAI). \\
\hline Ca30 EN & ND & East ND, East of the Nile Delta/ El-Maneyl, 17.6.1980, A. Bakry, 1229(CAI). \\
\hline Ca31 EN & ND & East ND, East of the Nile Delta/ El-Mullok, 25.4.1980, A. Bakry, 283(CAI). \\
\hline Cs32 BO & $\mathrm{O}$ & Baharia Oasis, El-Helz, Tabliun, 15.5.1978; Monier Abd El Ghani, 320(CAI). \\
\hline Cs33 WD & ED & Wadi Degla, Wadi Degla, Eastern Desert, 25.4.2006, M. Abdel Aleem; L1. (CAI). \\
\hline Ca34 DAM & $\mathrm{Nv}$ & Damanhour, 15.8.1907, G. Maire; 5971(CAI). \\
\hline Ca35 DAK & Nv & Dakahlia, the drain going parallel to the railways at Kilo 27 after Kaha, 21.7.1954; 5995(CAI). \\
\hline Сa36 BH & Nv & Beheira, Boghaz, Rosetta, 30.10.1971; 5991(CAI). \\
\hline Ca37 BO & $\mathrm{O}$ & Baharia Oasis,-Al-Harra, Ain Boulol, on walls \& hedges, 24.10.1979; Monier Abd El Ghani , 2112(CAI). \\
\hline Ca38 SHR & $\mathrm{Nv}$ & El-Sharqia, Ezbet EL Dleba, on gawsah drain:Hefna, 3.9.1953; Nabil El Hadidy 5994(CAI). \\
\hline Ca39 EN & ND & $\begin{array}{l}\text { East ND, East of the Nile Delta/ El-Maneyl, } 12 \mathrm{~km} \text { from Ismaila on the desert road, 17.6.1980, Leg. A. Bakry } \\
\text { 1229(CAI). }\end{array}$ \\
\hline Ca40 EN & ND & East ND, Cairo: Ain Shams University, 1977; A. Gazzar 5988(CAI). \\
\hline Ca41 DAK & Nv & Dakahlia, Dakahlia- Aga, 11.10.1929; E. Greiss 6005(CAI). \\
\hline Ca42 DAK & Nv & Dakahlia, Dakahlia- Aga, 11.10.1929; E. Greiss 6006(CAI). \\
\hline Ca43 DAK & $\mathrm{Nv}$ & Dakahlia, Dakahlia- Aga, 11.10.1929; E. Greiss 6007(CAI). \\
\hline Ca44 DEM & $\mathrm{Nv}$ & Demietta, Between Ras el Bar and Demietta, 13.9.1929; M.T. Hefnawy, 5983(CAI). \\
\hline Ca45 DEM & Nv & Demietta, Between Ras el Bar and Demietta, 13.9.1929; M.T. Hefnawy, 6002(CAI). \\
\hline Ca46 DEM & $\mathrm{Nv}$ & Demietta, Between Ras el Bar and Demietta, 13.9.1929; M.T. Hefnawy, 5972(CAI). \\
\hline Ca47 DEM & Nv & Demietta, Between Ras el Bar and Demietta, 13.9.1929; M.T. Hefnawy 5976(CAI). \\
\hline Cs 48 EN & ND & East ND, East of the Nile Delta/ El-Adlyah company for land reclamation, 14.9.1981; A. Bakry,. 3175(CAI). \\
\hline Cs 49 SR & $\mathrm{Nv}$ & El-Sharqia, Ezbet EL Dleba, on gawsah drain: Hefna, 3.9.1954; Nabil El Hadidy 5993(CAI). \\
\hline $\mathrm{Ca} 50 \mathrm{BH}$ & $\mathrm{Nv}$ & Beheira, Along the delta road to Edfina at sandioun, 29.9.1966; N. Hadidi M.Imam and V. Tackholm 5996(CAI). \\
\hline $\mathrm{Ca} 51 \mathrm{BH}$ & $\mathrm{Nv}$ & Beheira, Along the delta road to Edfina at sandioun, 29.9.1966; N. Hadidi, M.Imam and V. Tackholm 5997(CAI). \\
\hline Ca52 GZ & ND & Giza, At Parks and gardens, 10.10.1967; M. El-Mahdi 6045(CAI). \\
\hline Ca53 GZ & ND & Giza, At Parks and gardens / Orman Gardens, Giza, 27.8.1963; M. El-Mahdi 6048(CAI). \\
\hline Ca54 GZ & ND & Giza, At Parks and gardens, 10.10.1967; M. El-Mahdi 6050(CAI). \\
\hline Ca55 OV & ND & Giza, Olive orchard, 16.11.2010; Bennoba s.n. (CAI). \\
\hline Ca56 NT & ND & Beheira, Wadi El Natraun, in Olive orchard, 18.7.2009; A. B. Farhat. \\
\hline Ca57 RY & ND & Fayoum,Wadi Wl. Rayan protected area herbarium,1.2.2000; L.Boulos (CAI). \\
\hline Ca58 S & & Damascus, Demaecue, 23.8.1959; S. Ghabbour. 6043(CAI). \\
\hline Ca59 S & & Damascus, Demaecue, 23.8.1959; S. Ghabbour. 6044(CAI). \\
\hline Ca60 F & ND & Qasr Rashwan Tameyah, Fayoum, 29²7'30.4"N,3055'22.5"E; 25.8.2017; M. Sayed, M. Faker \& F. Yousef; CF1. \\
\hline Ca61 F & ND & Madinet Tameyah, Fayoum, 29²9'02.2"N, 3056'28.1"E;25.8.2018; M. Sayed, M. Faker \& F. Yousef; CF2. \\
\hline Ca62 F & ND & $\begin{array}{l}\text { Ezbet El-Hariry, El-Rawda, Tameyah, Fayoum; 2927'38.8"N 3058'41.5"E, 25.8.2019; M. Sayed, M. Faker \& F. } \\
\text { Yousef; CF3. }\end{array}$ \\
\hline Ca63 F & ND & Madinet Tameyah, Fayoum; 29²9'25.5"N, 3058'41.9"E; 25.8.2020; M. Sayed, M. Faker \& F. Yousef; CF4. \\
\hline Ca64 F & ND & Kafr Al Maslat - Tamya, Fayoum,29³2'52.5"N 3058'55.9"E ;25.8.2021; M. Sayed, M. Faker \& F. Yousef; CF5. \\
\hline Ca65 F & ND & $\begin{array}{l}\text { Monshaat Doctor El-Gammal, Fayoum, 29³0'32.1"N 3103'21.3"E; 25.8.2022; M. Sayed, M. Faker \& F. Yousef; } \\
\text { CF6. }\end{array}$ \\
\hline Ca66 F & ND & Forqos, Tameyah, Fayoum,29²5'28.4"N 3058'50.4"E;25.8.2023; M. Sayed, M. Faker \& F. Yousef; CF7. \\
\hline Ca67 F & ND & $\begin{array}{l}\text { Al Gharq-Faiyum way Izbat Ad Daw, Minya, Etsa, Fayoum; 29¹2'44.4" N 3045'50.1"E; 16.9.2017; M. Sayed, M. } \\
\text { Faker \& F. Yousef; CF8. }\end{array}$ \\
\hline Ca68 F & ND & $\begin{array}{l}\text { Madinat Al Fayoum - Tersa way -Naqalifah, Fayoum, } 29^{\circ} 24 \text { '39.8" N 3049'31.9"E; 16.9.2018; M. Sayed, M. Faker } \\
\text { \& F. Yousef; CF9. }\end{array}$ \\
\hline Ca69 F & ND & Al Eelam Al Fayoum, Fayoum, 29¹9'38.2"N 3052'07.5"E;20.9.2017; M. Sayed, M. Faker \& F. Yousef; CF10. \\
\hline Cl.70 FL & USA & Prince George Co., Illinois, USA; 10.8.1939; L. B. Smith; R. P. underlin; Barcode:13667. \\
\hline Cl.71 FL & USA & Halifax Co., North Carolina, USA;19.7.1956; H. E. Ahles; R. P. underlin; Barcode:20265. \\
\hline Cl.72 FL & USA & Jasper Co., Missouri, USA; 8.8.1920; E. J. Palmer; R. P. Wunderlin; Barcode:29684. \\
\hline Cl.73 FL & USA & Fairfax Co., Virginia, USA; 7.8.1910; P. Dowell; R. P. Wunderlin; Barcode:29685. \\
\hline Cl.74 FL & USA & Hamilton Co., Ohio, USA;7.8.1882; C. G. Lloyd; R. P. Wunderlin; Barcode:33754. \\
\hline Cl.75 FL & USA & Sharkey Co., Mississippi, USA;11.7.1955; J. D. Ray, Jr.; R. P. Wunderlin; Barcode:41111, \\
\hline Cl.76 FL & USA & Mercer Co., Kentuchy, USA;23.7.1955; M. E. Wharton; R. P. Wunderlin; Barcode:43698. \\
\hline Cl.77 FL & USA & Union Co., Illinois, USA; 23.8.1958; R. F. Thorne; R. P. Wunderlin; Barcode:53192. \\
\hline Cl.78 FL & USA & Independence Co., Arkansas, USA; 6.7.1968; R. D. Thomas; Barcode: 86801. \\
\hline Cl.79 FL & USA & Macon Co., Tennessee, USA; 14.10.1968; K. E. Rogers; D. Drapalik; Barcode: 86937. \\
\hline Cl.80 FL & USA & Macon Co., Tennessee, USA; 14.10.1968; K. E. Rogers; D. Drapalik; Barcode: 94278. \\
\hline Cl.81 FL & USA & Cocke Co., Tennessee, USA; 29.7.1977; P. Genelle; Barcode: 95410. \\
\hline Cl.82 FL & USA & Lincoln Co., Missouri, USA; 10.8.1978; W. G. D'Arcy; B. Summers; Barcode: 214841. \\
\hline Cl.83 FL & USA & Westmoreland Co., Virginia, USA; 7.7.1990; T. R. Bradley; Barcode: 215064. \\
\hline Cl.84 FL & USA & Champaign Co., Illinois, USA; 10.8.2008; S. R. Hill; S. R. Hill; Barcode: 277162. \\
\hline Cl.85 FL & USA & Jackson Co., Illinois, USA; 23.7.1998; S. R. Hill; S. R. Hill; Barcode: 283635. \\
\hline
\end{tabular}

